\title{
Antoni Szwed, Fideizm Kalwina i bunt angielskich racjonalistów [Calvin's Fideism and the defiance of English rationalists], Marek Derewiecki Publishing, Kęty 2016, pp. 373
}

Indubitably, the reviewed monograph by Antoni Szwed fills a major gap in the area of studies undertaken in Poland over the process of abandoning supernatural theology in England, as suggested by John Calvin (1509-1564), and approaching non-confessional natural theology proposed by the English Deists. Although the author of the paper which has the nature of a philosophical and theological study embedded in the historical context as he announces in the Preface is aware of not being capable of exhausting this complex and extensive subject within one study, he presents a neat and wellcomposed whole to the reader. The aim is quite distinctly delineated; references to historical facts have been accurately selected, and the cited source texts are viewed critically. The study also contains a well-balanced description of everyday life of the people from the period. The result is a compendium of knowledge which gathers together the most representative views on the issues discussed. In future, it may become a starting point for further studies and discussions as regards more detailed issues.

The monograph entitled Fideizm Kalwina i bunt angielskich racjonalistów. Wplyw fideizmu kalwińskiego na powstanie i rozwój racjonalnej teologii naturalnej u wybranych myślicieli angielskich XVII i XVIII wieku [Calvin's Fideism and the defiance of English Rationalists. The impact of Calvin's Fideism on the emergence and development of rational natural theology in selected English thinkers of the 17th and 18th centuries] is composed of a preface, eight chapters, a conclusion, an abstract in English, a collection of drawings, bibliography, and the index of persons. According to Szwed's announcements contained in the Preface, the consecutive chapters lead the reader chronologically through the stages of the influence that Calvin's Fideism had on the 
development of rational natural theology. This manner of broaching the subject, obvious as it is, does not evade faults, the most notable of which being the necessity to reiterate that results from the need to juxtapose subsequent conceptions as well as the inevitable abridgement. ${ }^{1}$ This, however, should not come as a surprise in a work which encompasses two centuries of religious, philosophical, and political discussions, and therefore, this fact does not depreciate its value.

Chapter One of the monograph, which introduces the subject, was dedicated to the figure of John Calvin and the fruit of his work of twenty-four years: Institutio christiane religionis. Having outlined some of the most important events in Calvin's life, Szwed analyses the manner of interpreting the word of God from the Holy Scriptures by the Reformer of Geneva. ${ }^{2}$ He refers to both, St. Augustine (354-430) and Martin Luther (1483-1546). The most vital problems undertaken in the chapter include the issue of double predestination which followed from Calvin's literal and selective interpretation of the Holy Scriptures. It refers to the image of unjust God, which Calvin had to agree with, pointing to the discrepancy between God's and Man's justice and the impossibility to learn God's will by a human mind as a result of the original sin. Szwed writes: "Revealed crumbs of divine truth are possible ow-

${ }^{1}$ Considering the task that the author set himself, the choice of thinkers whose views are critically analysed in the work seems to be appropriate. When considering the relationship between the Biblical Revelation, supernatural theology and various natural theologies, Szwed is forced to refer to those of them who write about those issues, and play important roles in the evolution that he describes. Thus, although the number of works from that period is vast, not each one of them is equally valuable. And although in a monograph dedicated to English rationalists the reader might miss such rationalists as Hobbes, he does not fit in within the outline of the deliberations. Perhaps if the formula of the paper was broader, then it could include the ideas contained in Hobbes' Elements of Law, Natural and Politic from 1640, which describes the issue of cognising God, his attributes, laws and revelations, and the Holy Scriptures in detail.

${ }^{2}$ Recognition should be given to the abundance of quotations from Calvin's work, which are, I assume translated and commented on by Szwed, including his comments that account for the terms used and their multiple meanings.. The author relates to the Latin version of the last 1559 edition. The same refers to Latin, Greek and English excerpts and quotations scattered across the reviewed work, and which have today fallen into disuse, and their meanings either faded away or gained new interpretations. Due to the fact that the excerpts are quoted in numerous footnotes in their original versions and the source terms are left in brackets, the reader may feel like they are reading the original source text fragments, and also use this opportunity to enrich their terminology (chiefly English) as regards obsolescent lay titles, hierarchs of ecclesiastical structures, legal acts, technical terms or simply words in everyday use. 
ing to grace, not human mind. The latter is 'blind' and 'shrouded in darkness', unable to 'capture God's will' and be 'pervaded' by God's will'. ${ }^{3}$

Chapter Two presents a historical background for the analysed reforms of the Church of England. It covers the period from the marriage of Henry VIII with Catherine of Aragon, through the reign of his son Edward VI, daughters Mary and Elisabeth I, and then James I and his son Charles I, until the death of Oliver Cromwell in 1658. This was the background against which English Puritans are shown. The author of the paper provides a detailed description of everyday life of a Puritan together with the issues of importance for them, such as piety, forms of faith, and the attitude towards double predestination. At the same time, Szwed cites numerous documents regarding the essence and interpretation of the Holy Scriptures, the issue of regarding Christ as an Intermediary and the Redeemer, predestination, the original sin, penance, reformation, and many other issues that were important to the congregation of that time.

In chapter Three, the issue of Calvin's understanding of double predestination returns. Here, it is juxtaposed with its critical reception by Jacob Arminius (1560-1609). This Dutch theologian was the first to attack the suspect opinion by Calvin concerning grace and salvation, while at the same time highlighting the fallacious and biased selection of the Holy Scripture fragments suggested by the reformer from Geneva. He undermined the reliability of Calvin's works by highlighting the lack of those among them which refer to God as charity. According to Arminius, God cannot be the cause of man's sin, and the dogma of double predestination itself is internally contradictory. This feud commenced the process of departing from the literal interpretation of the Holy Scriptures, and the Arminianism itself largely contributed to the rebuttal of Calvin's Fideism.

In chapter Four, the author of Calvin's Fideism points to more reasons for the fall of Puritanism which include: "the Erastianism in England, i.e. the prevalence of lay authority over religious matters, ${ }^{4}$ common intolerance between numerous religious communities and sects, and the phenomenon of religious 'enthusiasm' which is inextricably connected with this issue". ${ }^{5}$ The part dedicated to Oliver Cromwell (1599-1658) has been used to depict the

\footnotetext{
${ }^{3}$ A. Szwed, Fideizm Kalwina i bunt angielskich racjonalistów, Marek Derewiecki Publishing, Kęty 2016, p. 237.

${ }^{4}$ At this juncture it would be appropriate to at least delineate the opinions of Hobbes on this matter.
}

${ }^{5}$ A. Szwed, op. cit., p. 11. 
manifestations of Puritanism in social life. ${ }^{6}$ The opinions by Locke and Tilloston on this issue are presented as a representative approach towards overexpressing religious feelings. The remaining part of the text was dedicated to the issue of tolerance, both to opposing opinions (e.g. by Francis Bacon, Rogera L'Estrange or Edward Stillingfleet), and completely or only partially favourable (e.g. John Locke). Antoni Szwed complements this part of deliberations with the presentation of direct and indirect political consequences of the both stances such as partial influence of Locke's Letter Concerning Toleration on the Act of Toleration of 1689 proclaimed by William of Orange.

The next chapter of the paper briefly presents first attempts at the liberalisation of Calvin's theology. Szwed discusses this process utilising the opinions of three intellectuals: Thomas Browne (1605-1682), John Hales (1584-1656) and William Chillingworth (1602-1644). By making use of source materials, he demonstrates that each one of them was seeking a criterion or a remedy for putting an end to inter-religious feuds in the reason, or at least a chance to understand the underlying causes of such a state of affairs. The works of the trio are increasingly manifesting a willingness to free the reason from the shackles of Fideism. The author of the monograph differentiates their opinions and points to the most important elements for each of them.

Chapter Six introduces the reader to the period of Restoration after the enthronement of Charles II. Szwed embeds the most important reforms that took place in the Anglican Church at that time against the historical context which was departing from the rigid Calvinist dogmatism. Highly influential for the course of this departure was a group of the so-called Latitudinarians, i.e. theologians with a relatively free-thinking attitude. Their main objective was to eliminate irrational elements from Christian religion; however, as the author of the reviewed work rightly observes: "It was not an attempt to substitute faith with reason or eradication of the most fundamental mysteries of Christianity". The term latitudinarian has not been accurately defined even until today. John Tulloch, for example, places all the Cambridge Platonists among them whereas Gerard Cragg - an entire theology of the second half of the $17^{\text {th }}$ century. ${ }^{8}$ In this chapter, Szwed focuses mainly on the reconstruction

${ }^{6}$ It is worth adding here that Shaftesbury in his Letter Concerning Enthusiasm of 1708, makes attempts at vindicating this phenomenon by pointing to its non-religious dimension and entering it within an aesthetic experience.

${ }^{7}$ A. Szwed, op. cit., p. 201.

${ }^{8}$ Information cited from A. Szwed, op. cit., p. 199. Cf. also J. Tulloch, Rational Theology and Christian Philosophy in England in the Seventeenth Century, vol. II, William Blackwood 
of the opinions of two of them: Benjamin Whichcote (1609-1683) and John Smith (1618-1652). Having presented the elements of their biographies, he gives an account of how they searched for "philosophical balance between Christian Revelation and natural theology, which was supported by the neoplatonic thought". 9 . Whichcote believed in the power of reason to such an extent that he believed it was possible to indicate such fragments of the Holy Scriptures that the Puritans, Catholics, Socinians, and others would agree on. By doing so, he anticipated an analogical stance by Locke, although for him tolerance was not concerned with Catholics or Atheists. However, the both attempted at an accurate indication of the use of reason in the scope of the Bible studies, although Whichcote himself was not in the position to establish precisely what the reason was. Nevertheless, he underlined its role in proving divine authority of the Holy Scripture whose veracity, in his opinion, required a rational confirmation. ${ }^{10}$ John Smith, on the other hand, focused on debunking a fallacious image of the Deity and fighting all superstitions that concerned it. He argued that the true path to God led through the purification of the soul, and one should start the quest for him in oneself, not in philosophical works and disputes. The both were characterised by an aversion towards excessive religious feelings and contrasted reason with enthusiasm.

Subsequent stages of rationalising Christianity is presented by Szwed in Chapter Seven which is dedicated to the figures of John Tillotson (1630-1694) and John Locke (1632-1704). The former stroves to make rational grounds for Calvinist theology, whereas the latter wished to reconcile the divided religions and establish a scope of knowledge available to human reason. Detailed analyses refer to the question of natural morality and the role of conscience in human life (in the case of Tillotson), as well as epistemological grounds of his philosophy, a critical approach to selected content of the Holy Scriptures and establishing the reason as the arbitrator of their truthfulness (in Locke).

The last, Chapter Eight, was devoted to Deists in its entirety: John Tolando (1670-1722) and Matthew Tindal (1657-1733). As Szwed rightly observes, both of them in their works "try to convince the reader that the Christian evangelical message does not add anything to natural theology based on natural law understood broadly. Christianity, in their opinion, is devoid of the

\& Sons, Edinburgh and London 1874, pp. 6-8, and G. R. Cragg, From Puritanism to the Age of Reason, University Press, Cambridge 1966, pp. 61-63.

${ }^{9}$ A. Szwed, op. cit., p. 11.

${ }^{10}$ Ibid., p. 337. 
proper, whereas its beginnings lose their importance as the main Event in the history of mankind". ${ }^{11}$ Both of them, following Locke, wish to put an end to doctrinal feuds and the spreading religious intolerance. Similarly, they are looking for a common platform for reaching agreement in human reason. However, they go further than the author of Reasonableness of Christianity: Toland deprives Christianity of all the mystery, whereas Tindal tries to prove that Christianity had existed since the beginning of history, and the Revelation of the Old and New Testament had not contributed to understanding it better. The latter makes the Gospels equal with the republication of the religion of nature claiming that Christian religion had been granted once and for all in the form of a religion founded on the natural law. ${ }^{12}$

It should be concluded that the monograph by Antoni Szwed is an impressive compendium of knowledge with added cognitive value. Occasional coarseness of the style or misprints do not overshadow its substantive value. The wealth of the analysed source literature as well as the use of classical works or the most recent publications turn the book into a cohesive and complete whole. The chapters are linked to each other in a clear and logical way so that the reader easily follows the main course of the author's arguments, as well as each and every side thread. A proper balance of all its parts and the contents of the work is conducive to a very good reception and gives a ground for conclusions that will contribute to the growth of interest in this subject in Poland and result in further works devoted to it.

Krzysztof Wawrzonkowski

Nicolaus Copernicus University, Toruń, Poland e-mail: kwawrzonkowski@umk.pl

\footnotetext{
${ }^{11}$ Ibid., p. 12.

${ }^{12}$ Cf. A. Szwed, op. cit., p. 348.
} 